Article

\title{
Perceived Climate Variability and Farm Level Adaptation in the Central River Region of The Gambia
}

\author{
Abdoul Rasmane Bagagnan ${ }^{1, *(1)}$, Issa Ouedraogo ${ }^{2}$ and William M. Fonta ${ }^{3}(\mathbb{C}$ \\ 1 International Livestock Research Institute (ILRI), West Africa regional office, \\ 01 BP 1496 Ouagadougou, Burkina Faso \\ 2 The CGIAR Program on Climate Change, Agriculture and Food Security (CCAFS), ICRISAT West \& Central \\ Africa Regional Office, BP 320 Bamako, Mali \\ 3 West African Science Service Center on Climate Change and Adapted Land Use (WASCAL), \\ 06 BP 9507 Ouagadougou, Burkina Faso \\ * Correspondence: B.Rasmane@cgiar.org
}

Received: 14 June 2019; Accepted: 17 July 2019; Published: 23 July 2019

\begin{abstract}
In Sub-Saharan Africa, the recurring erratic and uneven rainfall distribution has resulted in low crop yields, income losses, and low food stock. In response to these climate change challenges, farmers have recourse to several coping strategies to survive. This present paper explores farmers' perception of climate variability and the coping strategies in use in the Central River Region of The Gambia. The main purpose of this paper is to analyze perceived climate variability and farm level adaptation options in the region. Data were collected from 283 farmhouses through transect walks, quantitative surveys including the use focus group discussions. Data were analyzed using descriptive and inferential statistics. Results revealed that farmers generally perceive an increase in the frequency of extreme weather events and a decrease in the duration of the growing season. With regards to vulnerability and severity, nearly $95 \%$ of the respondents considered the dryness as the main threat to their farming activities and perceived its consequences as the most severe. The results equally showed that the perception of changes is linked to the adoption of some adaptation measures among which the preferred were the use of chemical fertilizers $(66 \%)$, though it is stated to be the most expensive. The Spearman correlation test showed that the use of water conservation techniques is highly correlated with the quality of soil surface structure $(p \leq 0.01)$ and soil storage capacity $(p \leq 0.01)$. Findings of this study are of paramount importance in planning and implementing adaptation policies in The Gambia and beyond. To improve farmers' resilience, drought tolerant crops should be promoted along with climate change and variability awareness campaigns.
\end{abstract}

Keywords: climate variability; extreme weather events; perceptions; adaptation measures; The Gambia

\section{Introduction}

Change in the global energy budget has been observed and is expected to exhibit natural variations [1]. The recent food crisis in West Africa has revealed that this part of Africa is highly vulnerable to climate variability and change [2]. With heavy reliance on rainfed agriculture, Africa is believed to be one of the most vulnerable continents to climate change [3]. Droughts of the 1970s and 1980s have put the West African Sahel region in the spotlight of environmental and climate change-related research [4]. The Gambia, due to its location at the southern fringe of the Sahara desert where rainfall is irregular and unpredictable, is particularly prone to drought. In The Gambia, agriculture employs approximately $75 \%$ of the labor force and contributes to $33 \%$ of the GDP. Agriculture 
is the second largest sector in the economy [5]. However, the recurrent erratic and uneven rainfall distribution in the country has resulted in low crop yield and production, sometimes causing food shortage in the country [6]. In 2006, for instance, it was reported that $46 \%$ of rural households fell below the food poverty line [7]. The food shortage continued from 2008 to 2013 following the drastic fall in agricultural production caused by the severe drought crises that affected the country [7]. Smallholder farmers were the most affected due to their high sensitivity and low adaptive capacity [8,9]. Simulation models such as DSSAT(Decision Support System for Agrotechnology Transfer) and APSIM(Agricultural Production Systems sIMulator) showed that agricultural production, especially maize production, was expected to be dramatically reduced by the year 2055 if the current trend of the climate variability is maintained [10].

Farmers' perception plays a key role in the adoption of innovative technology [11,12]. Perceptions of the evolution of climate variables vary across different climatic zones in Africa [13,14]. A study conducted in southwestern Burkina Faso revealed that farmers' awareness of the ongoing climate and environment change depends on their experienced historical weather and climate [15]. In Senegal and Kenya, for example, most farmers perceived variations in the frequency of drought events [16]. In the savanna zone of Senegal, farmers associate the effects of climate variability with the occurrence of violent winds and occasional storms [17,18]. In the Central plateau of Burkina Faso, farmers perceived a decrease in the average annual rainfall and the number of heavy rains [4]. In Ghana and Niger, farmers' perceptions are in line with meteorological data [16]. Different factors affect farmers' perception and adaptation to climate change [13], including factors that are not related to weather or environment but grounded on local social dynamics and sense-making around them [17]. Factors that influence farmers' perception may include farm size, access to training, household size, and membership of farmer-based organizations [19]. For instance, flood events are found to have an impact on people's perception about climate change [20]. In some studies, farmers' perceptions corroborate observed meteorological data [21,22], whereas others contradict this view [18].

Most studies on farmers' perception of climate variability compare their findings with empirical meteorological data and, at times, have linked it to the adaptation practices used by farmers (e.g., [23,24]). Little attention has been paid to how farmers perceive their own exposure (vulnerability) to perceived climatic changes and possible losses that result from it (severity). Moreover, few studies have been conducted on farmers' preferences of the available adaptation measures in terms of cost and effectiveness. Until recently, few studies in this field have been published on The Gambia [9]. Most of these studies such as Jallow et al. [25] and Yaffa [9] did not look at farmers' perception of climate change as a threat that may increase their own vulnerability. Indeed, most studies focused on the North Bank Region, which is the driest zone of the country. The Central River Region (CRR), which is considered as the "food basket" of The Gambia is a relevant location for this study as it could be an important contribution to the farmers' resilience building for improved food productivity and poverty alleviation. The present study specifically responds to the questions: (i) what is the farmers' perceived trend of climate variability? (ii) what are the adaptation measures used by farmers? (iii) what is the linkage between the perceived trend and the use of adaptation measures?

\section{Materials and Methods}

\subsection{The Central River Region (CRR) of The Gambia}

The study was conducted in the CRR of The Gambia (Figure 1). The CRR covers about 2894 $\mathrm{km}^{2}$ and is home of 226,000 people with a density of 78 inhabitants per $\mathrm{km}^{2}$. The main activities in the region are livestock husbandry and rice production. With a majority of Fula cattle owners living in CRR, it is estimated that over half of Gambia's cattle are raised in this region. Fula peoples are Muslim in majority. Other groups in CRR include Mandinka, Jola, Wolof, and Sarahule. The CRR plays an important role for national agriculture and hosts the first ever established agricultural training centers of the country in Fula Bantang and Sapu. 


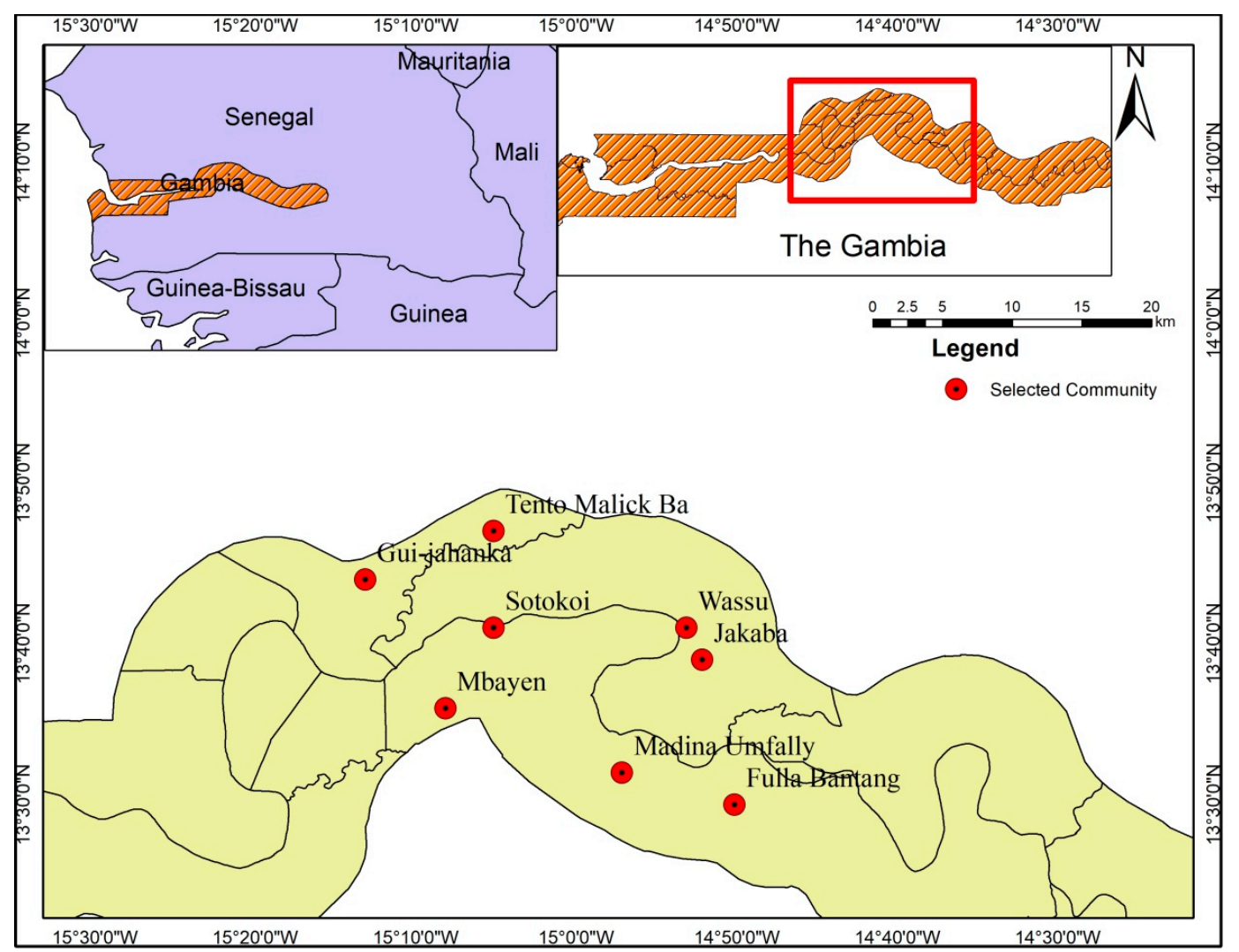

Figure 1. Map of the study sites.

\subsection{Data Collection}

The study was conducted in purposely selected four districts in the CRR: the Upper Saloum and Niani in CRR North, Niamina East, and Lower Fulladu West in CRR South in order to cover as much geographic diversity as possible, and thus exploring the variability of adaptation measures used in the region. With the assumption that the adaptation measures could vary little within a district, two communities were selected randomly [26] in each district based on a list of the communities per district collected from the Gambia Bureau of Statistics. Households in each community were randomly selected based on the lottery method [27] using the list of household heads provided by the local chief (alkalo).

Three research instruments were used to collect the data: a household survey covering 283 farm households, walk-about interviews along a transect and focus group discussions (FGD). The survey questionnaire, adapted from Karrer [28] had four distinct sections: (a) Perception of the evolution of extreme weather events and climate related factors, (b) Perception of coping strategies, (c) Motivation to protect the farm, and (d) internal multipliers and barriers to proenvironmental behavior, as well as sociodemographic and farm-specific variables.

The walk-about interviews methods, adapted from FAO [29], were used to systematically collect data on adaptation measures used on farms in the study area. The walk was done with two to three lead-farmers following a straight line from the village center to the limit of the farms. The FGDs were conducted in all the eight communities. Referring to Stewart, et al. [30], seven to ten farmers were selected per community in a balanced gender-mixed setting.

\subsection{Data Analysis}

Out of 285 administrated forms, 283 forms were correctly filled and considered for the data analysis using SPSS. Quantitative data were analyzed using descriptive statistics. The Spearman correlation was performed to find out whether the perception of climate variability plays a significant role in the 
implementation of the adaptation measures. The inferential statistics, namely, binary logistic regression was performed to further figure out how the implementation of the adaptation measures (e.g., use of chemical fertilizers) is influenced by some perception variables and socio-economic variables. The dependent variables were the perception of the length of the growing season, the perception of the longer period of drought, the farm size, and farm income (Table 1). The method used in the regression was "forward LR". This method generates the result of four different models in four steps by removing one variable at each step.

Table 1. List of the variables in the binary logistic regression.

\begin{tabular}{ccc}
\hline Abbreviation & Variable Name & Variable Description \\
\hline Use of Chemical Fertilizers & Use of Chemical Fertilizers & $\begin{array}{c}\text { Categorical Variable: } \\
1 \text { = Implemented, } \\
2=\text { Not Implemented }\end{array}$ \\
\hline LPODT & Longer period of drought & $\begin{array}{c}\text { Categorical variable: } 1=\text { decrease; } \\
2=\text { no change; } 3=\text { increase }\end{array}$ \\
\hline LOGST & Length of the growing season & $\begin{array}{c}\text { Categorical variable: } 1=\text { decrease; } \\
2=\text { no change; } 3=\text { increase }\end{array}$ \\
\hline Sodem 4 & Farm size & Continuous variable \\
\hline Sodm5 & Annual income & Continuous variable \\
\hline
\end{tabular}

Binary logistic regression model:

In the binary logistic regression, the natural logarithm of the odds ratio is equal to a linear function of the independent variables expressed as:

$$
\log i \mathrm{Pi}=\ln (P i \mid 1-P i)=\beta 0+\beta 1 X 1
$$

Using the antilog function followed by some mathematical transformation, the value of $P i$ (probability of implementation of chemical fertilizers for the ith respondent) is:

$$
P i=1 / 1+e^{-(\beta 0+\beta 1 X 1)}
$$

For simplicity purposes, Equation (2) become

$$
P i=1 / 1+e^{-Z I}
$$

where $Z I$ = function of explanatory variables is expressed as:

$$
Z I=\beta 0+\beta 1 X 1+\beta 2 X 2+\ldots+\beta n X n+u i
$$

where: $\beta 0$ is the constant

$\beta 1 \ldots \beta n$ are regression coefficient; consequently,

$$
\mathrm{Zi}=\beta 0+\beta 1(\text { LPODT })+\beta 2(\text { LOGST })+\beta 3(\text { Sodem } 4)+\beta 4(\text { Sodem } 5)
$$

The qualitative data recorded with an audio recorder were first transcribed and written down for subsequent analysis. They were then organized by topics and the main topics were used to back up the results of the quantitative data. 


\section{Results}

\subsection{Perceived Trends in Climate Variability}

Table 2 shows the percentage of the respondents' perceived trend of five different variables related to extreme weather and climate events during the past 20 years. In general, the respondents perceive an increase in the heat and storm events and a decrease in the growing period and heavy rain events. About $85 \%$ of the interviewed farmers perceived an increase in heat of which nearly $20 \%$ perceived a very strong increase. Most of the respondents perceived an increase in storm $(77.8 \%)$, of which $14.5 \%$ stated the storms are getting stronger and stronger. However, farmers perceived a decreasing trend for the variables related to rainfall. For instance, the length of the rainy season is perceived by $70 \%$ of the respondent farmers to be shortening. About $79 \%$ of the respondents perceive that the number of the heavy rains has reduced during the last 20 years. During the FGDs, one of the participants stated that "Heat from the sun (environment) heats the soil and when both soil and environment heat combine, it affects the crop". Some respondents mention cutting down trees as well as war in the western world as causes of the observed changes. They went further to explain that trees would signify rainfall and that fewer trees would mean less rainfall.

Table 2. Percentage of the evolution of extreme weather events and climate factors $(\mathrm{N}=283)$.

\begin{tabular}{cccccccc}
\hline Events & $\begin{array}{c}\text { Strong } \\
\text { Decrease }\end{array}$ & Decrease & $\begin{array}{c}\text { Little } \\
\text { Decrease }\end{array}$ & $\begin{array}{c}\text { No } \\
\text { Change }\end{array}$ & $\begin{array}{c}\text { Little } \\
\text { Increase }\end{array}$ & $\begin{array}{c}\text { Increase } \\
\text { Increase }\end{array}$ \\
\hline Storm & 0 & 14.1 & 0.4 & 4.2 & 3.5 & 63.3 & 14.5 \\
Heat & 0 & 8.8 & 0.4 & 2.5 & 3 & 65.7 & 19.4 \\
Longer precipitation period & 1.8 & 68.2 & 4 & 11 & 2.1 & 24.7 & 1.8 \\
Heavy rain & 3.9 & 74.9 & 2.1 & 0.4 & 1.8 & 16.6 & 4 \\
Length of growing season & 13.4 & 64.3 & 7 & 11 & 1.4 & 18.0 & 1.1 \\
\hline
\end{tabular}

\subsection{Adaptation Measures Used by Farmers}

\subsubsection{Common Adaptation Measures and Preferences}

The transect walks at the beginning of the rainy season revealed various adaptation measures in the eight communities, namely, use of improved crop varieties, crop rotation, water conservation techniques, water diversion, use of natural and chemical fertilizers (Figure 2). In order to identify the most commonly used measures, a synthetic table was produced at the end of the transect walk using the following score: " 1 " for "practiced" and " 0 " for "not practiced" within the community. Measures such as the use of improved crop varieties (mainly NERICA for rice and early millet for millet), chemical fertilizers, natural fertilizers (crop residues, compound residues, animal manure), and crop rotation systems got a score of 8 , meaning that these adaptation techniques were practiced in all communities of the study area. The mixed farming technique (Most of the time maize and millet) got a score of 4, meaning that it was not widely practiced in the study area. Both the use of water conservation and water diversion systems were practiced in six communities. Water conservation was mainly used in lowlands ecology (rice cultivation in the form of permanent wetting system). In upland ecology, farmers claimed not to use any water conservation system. Therefore, it is not practiced in all the eight communities. Regarding respondents' preferences in terms of adaptation measures, the improved crop varieties, crop rotation, chemical fertilizers, and natural fertilizers got a score of 6 , meaning that most of the respondents stated a very strong preference for those measures. However, the water conservation technique and the water diversion technique got a score of 5 . This means that most of the respondents have a strong preference for those two measures. The second quartile (Q2) got a value of 6 for some selected measures such as "use of improved crop varieties", "use of chemical fertilizers", and "use of natural fertilizers" while for the others it was 5. This means that by classifying the respondents' stated preference in the order of preference, in the first $50 \%$, farmers have a very strong preference for those three measures while it is not the case for the others measures. 
Among the measures that got $\mathrm{Q} 2=6$, the use of chemical fertilizers got the highest mean (5.61) and the smallest standard deviation (0.634). Therefore, the use of chemical fertilizers tends to be the stated preferred measure by the respondents since it got the relative highest mean and its values are less spread around the mean as compared to the others measures.

\subsubsection{Degree of Implementation of the Adaption Measures}

To face the observed changes mentioned above, farmers do implement some adaptation measures. Almost all the common adaptation measures used in the study area were implemented by most of the farmers. The most implemented adaptation measure seems to be the crop rotation technique. In fact, by looking at the scale of "Always implemented", the crop rotation technique showed the highest frequency (see Figure 2). Water conservation technique seems to be the least implemented since it got the highest frequency when using the scale of "never implemented". Still using the scale of "always implemented", the water conservation technique is followed by the use of improved varieties, the use of natural fertilizers, and the use of chemical fertilizers. The use of Chemical fertilizers is ranked third though it is stated by the farmers as the most preferred adaptation measure. The cost might play a role in the implementation of this technique since it is stated as the most expensive one by the farmers.

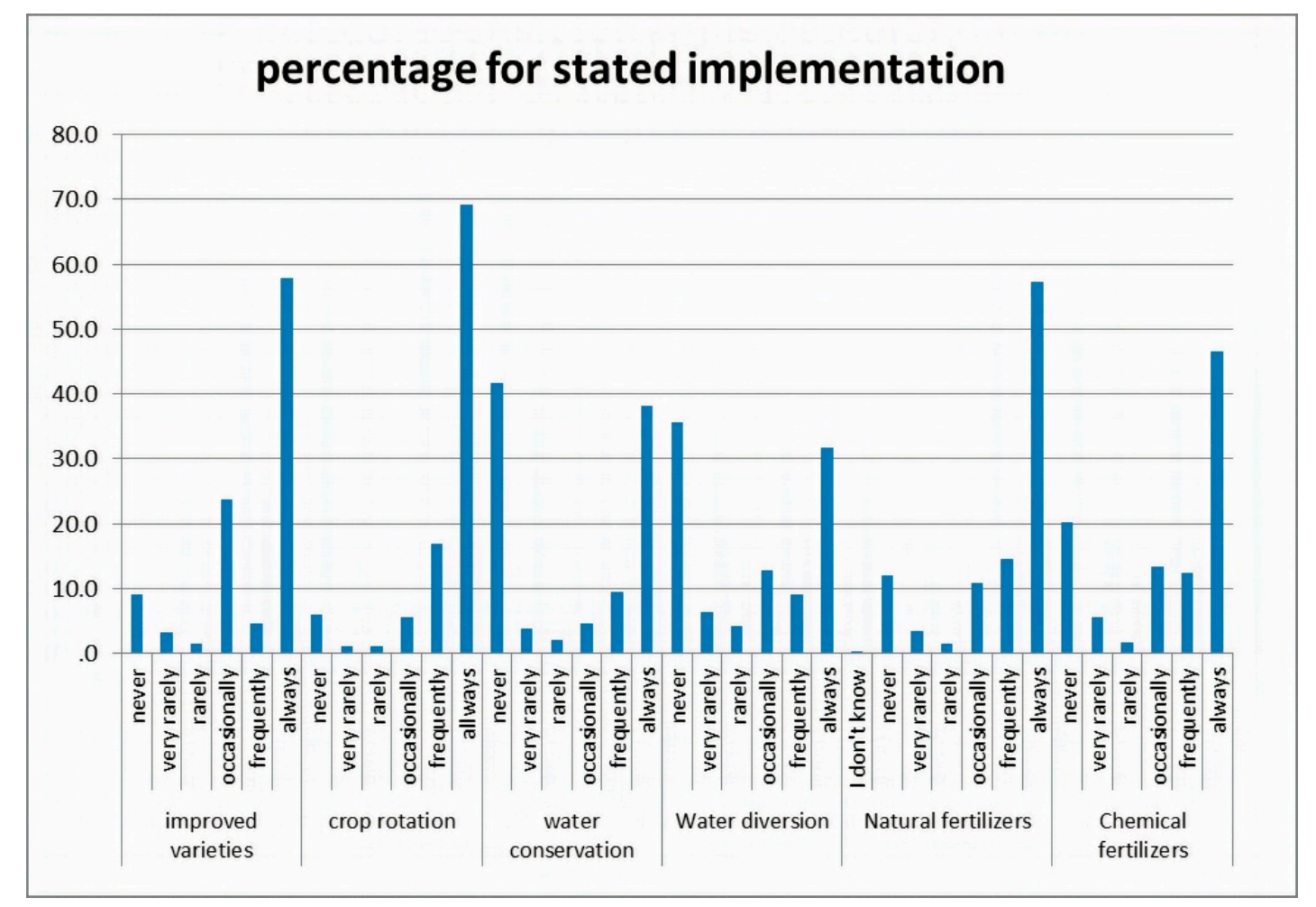

Figure 2. Stated implementation of adaptation measures.

\subsection{Linkage between the Perceived Trend and the Use of Adaptation Measures}

The Spearman correlation revealed that the length of the growing season is the only perception variable which is positive and significantly linked to all five adaptation measures (Table 3). The perception of heavy precipitation and soil water storage capacity has positive relationships with the use of chemical fertilizers, water conservation, and water diversion techniques. The perception of the longer precipitation period is positively liked to two adaptation measures, the water conservation technique and water diversion technique. The quality of soil surface structure has positive and statistically significant relationships with the use of water conservation techniques, water diversion, and chemical fertilizers. The use of the chemical fertilizers, which is the most preferred and the most expensive according to the farmers, is only significantly correlated with three perception variables. 
In the following section, this relationship is further analyzed including some socio-economic variables using a binary logistic regression.

Table 3. Spearman correlation between perception and stated implementation.

\begin{tabular}{|c|c|c|c|c|c|c|c|}
\hline & $\begin{array}{c}\text { Heavy } \\
\text { Precipitation }\end{array}$ & Storm & Heat & $\begin{array}{c}\text { Longer } \\
\text { Precipitation } \\
\text { Period }\end{array}$ & $\begin{array}{l}\text { Quality of Soil } \\
\text { Surface } \\
\text { Structure }\end{array}$ & $\begin{array}{l}\text { Soil Water } \\
\text { Storage } \\
\text { Capacity }\end{array}$ & $\begin{array}{c}\text { Length of } \\
\text { Growing } \\
\text { Season }\end{array}$ \\
\hline $\begin{array}{c}\text { Use of improved } \\
\text { varieties }\end{array}$ & 0.095 & 0.013 & 0.05 & 0.071 & -0.003 & 0.105 & $154^{* *}$ \\
\hline $\begin{array}{l}\text { Use of chemical } \\
\text { fertilizers }\end{array}$ & $118^{*}$ & 0.089 & 0.075 & 0.096 & 0.062 & 148 * & $212^{* *}$ \\
\hline $\begin{array}{c}\text { Water } \\
\text { conservation } \\
\text { techniques }\end{array}$ & $158^{* *}$ & -0.055 & 0.013 & $147^{*}$ & $155^{* *}$ & $186^{* *}$ & $244^{* *}$ \\
\hline $\begin{array}{l}\text { Water diversion } \\
\text { techniques }\end{array}$ & $227^{* *}$ & $119 *$ & -0.033 & $223^{* *}$ & $117^{*}$ & $186^{* *}$ & $204^{* *}$ \\
\hline $\begin{array}{l}\text { Use of natural } \\
\text { fertilizers }\end{array}$ & 0.026 & 0.032 & $-145^{*}$ & 0.111 & 131 * & 0.031 & $172 * *$ \\
\hline
\end{tabular}

Among the four steps, the model of step four seems to be the most adequate model since this has the highest value of classification and has more significant variables than the others (Table 4). The odds ratio of the longer period of drought (LPODT) is greater than 1 and significant $(0.010<$ 0.05). This means that farmers who perceive an increase in the longer period of drought rather than a decrease are likely to use the chemical fertilizers on their farms. The odds ratio of longer period of growing season (LOGST) is less than 1 and significant $(0.002<0.05)$. It means that farmers who perceive a decrease in the longer period of the growing season are unlikely to implement the chemical fertilizers in their farms. The odds ratio of the farm size (Sodem4) is less than 1 and significant. This means that when the farm size increases, farmers are unlikely to apply chemical fertilizers. In other words, the smaller the farm size, the most likely it is to receive chemical fertilizers. The odds ratio of the annual income (Sodem5) is equal to 1 and significant $(0.004<0.05)$. It means that the fertilizers implementation is not sensitive to annual income variation.

Table 4. Results of the binary logistic regression.

\begin{tabular}{|c|c|c|c|c|c|c|c|c|c|}
\hline \multicolumn{10}{|c|}{ Variables in the Equation } \\
\hline & & \multirow{2}{*}{ B } & \multirow{2}{*}{ S.E. } & \multirow{2}{*}{ Wald } & \multirow{2}{*}{ Df } & \multirow{2}{*}{ Sig. } & \multirow{2}{*}{$\operatorname{Exp}(B)$} & \multicolumn{2}{|c|}{ 95\% C.I. for EXP(B) } \\
\hline & & & & & & & & Lower & Upper \\
\hline \multirow{7}{*}{ Step $4^{\mathrm{d}}$} & LPODT(1) & 1.453 & 0.561 & 6.708 & 1 & 0.010 & 4.275 & 1.424 & 12.838 \\
\hline & LOGST & & & 9.350 & 2 & 0.009 & & & \\
\hline & LOGST(1) & -1.360 & 0.445 & 9.350 & 1 & 0.002 & 0.257 & 0.107 & 0.614 \\
\hline & LOGST(2) & 18.529 & $23,058.038$ & 0.000 & 1 & 0.999 & $111,461,088.539$ & 0.000 & \\
\hline & Sodem 4 & -0.091 & 0.024 & 14.244 & 1 & 0.000 & 0.913 & 0.871 & 0.957 \\
\hline & Sodm5 & 0.000 & 0.000 & 8.464 & 1 & 0.004 & 1.000 & 1.000 & 1.000 \\
\hline & Constant & 2.102 & 0.435 & 23.348 & 1 & 0.000 & 8.182 & & \\
\hline \multicolumn{10}{|c|}{$\begin{array}{l}\text { a. Variable(s) entered on step 1: Sodem4. } \\
\text { b. Variable(s) entered on step 2: LPODT. } \\
\text { c. Variable(s) entered on step 3: Sodm5. } \\
\text { d. Variable(s) entered on step 4: LOGST. }\end{array}$} \\
\hline
\end{tabular}

\subsection{Vulnerability and Coping}

\subsubsection{Perceived Vulnerability and Coping Capacity}

Respondents were asked to state their perception about their own vulnerability (thus their likelihood of being affected by extreme weather events) on a six-point Likert scale from "not at all" to "very likely" and to estimate the associated severity (the losses caused by the occurrence of the extreme weather events) on a six-point Likert scale from " $0 \%$ " to "more than $45 \%$ " (see Table 3). 
Most of the farmers perceived that they are vulnerable to drought $(95.8 \%)$. Around $96 \%$ of the farmers perceive that their losses are associated with drought, ranging from $10 \%$ to above $45 \%$. Most of the respondents (53.7\%) disagree to be able to face drought. Farmers perceived that they are vulnerable to heat. The mean values for all the items of vulnerability and severity are above 5 ( $5=$ likely for vulnerability and $5=30 \%$ to $45 \%$ of losses for severity). Around $72 \%$ of the respondents perceive that the losses associated with heat waves range from $45 \%$ and above. The proportion of farmers who believe that they can withstand flooding $(54.4 \%)$ is greater than those who think they can withstand a drought (39.9\%). Most FDG participants were Muslim and according to them, they tried to face flood although they believe that the last decision belongs to Allah (God). During the FGD, a participant from Sotokoi explained how they respond to flood: "When flood occurs, we plant upland and when the water reduces, we transplant into faros (lowland). In doing so, we save the situation but if God does facilitate, then we cannot save it. We can only pray to God. We can't give ourselves. It is only God who gives". However, during drought, the only way to save the crop is to irrigate. However, most farmers do not have access to water for supplementary irrigation and rely on rainfall.

\subsubsection{Perceived Cost and Effectiveness of the Adaptation Measures}

A frequency table of all the six items was used to discuss the perceived cost of the measures. The frequency of each variable was used to compare the perceived cost (Table 5). By using the scale of 'very expensive', the use of chemical fertilizers is ranked first with $66.4 \%$, followed by water conservation techniques $(21.9 \%)$, water diversion techniques $(18.4 \%)$, the use of improved varieties $(14.8 \%)$, use of natural fertilizers $(9.9 \%)$, and the cheapest one is crop rotation with $7.1 \%$.

Table 5. Perceived vulnerability, severity and coping capacity.

\begin{tabular}{|c|c|c|c|c|c|c|c|c|}
\hline \multicolumn{3}{|c|}{ Vulnerability } & \multicolumn{3}{|c|}{ Severity } & \multicolumn{3}{|c|}{ Coping Capacity } \\
\hline Perception & Dryness & Heat & Perception & Dryness & Heat & Perception & drought & Flood \\
\hline Very likely & 4 & 7 & I don't know & 4 & 4 & Strongly disagree & 2.1 & 2.1 \\
\hline Unlikely & 7 & 5.7 & Not at all & 4 & 1.4 & Disagree & 51.6 & 41 \\
\hline Little likely & 3.2 & 2.8 & Less than $10 \%$ & 3.2 & 3.9 & Somewhat disagree & 3.5 & 1.4 \\
\hline Likely & 43.1 & 41.7 & $10 \%$ to $20 \%$ & 2.1 & 2.8 & Somewhat agree & 2.8 & 1.1 \\
\hline \multirow[t]{3}{*}{ Very likely } & 52.7 & 49.1 & $20 \%$ to $30 \%$ & 5.3 & 6.4 & Agree & 31.8 & 38.9 \\
\hline & & & $30 \%$ to $40 \%$ & 12 & 13.1 & Strongly agree & 8.1 & 15.5 \\
\hline & & & $45 \%$ and above & 76.7 & 72.1 & & & \\
\hline
\end{tabular}

Table 6 is also used to classify the measure by looking at the scale of "very effective". The use of chemical fertilizers (usually NPK) was ranked first by the respondents with a frequency score of $66 \%$, followed by natural fertilizers (51.6\%) and use of improved varieties (49.8\%). Crop rotation system has a frequency of $46 \%$, with $34 \%$ for water diversion system, and $28 \%$ for the water conservation system.

Table 6. Frequency table.

\begin{tabular}{cccc}
\hline \multirow{2}{*}{ Technology } & \multicolumn{2}{c}{ Frequency N = 283 } & Mode N $=\mathbf{2 8 3}$ \\
\cline { 2 - 4 } & Stated Very Effective & Stated Very Expensive & \\
\hline Improve varieties & 141 & 42 & 5 \\
Crop Rotation & 129 & 20 & 2 \\
Chemical fertilizers & 188 & 188 & 6 \\
Water Conservation Techniques & 81 & 62 & 5 \\
Water diversion Techniques & 97 & 52 & 5 \\
Use of natural Fertilizers & 146 & 28 & 5 \\
\hline
\end{tabular}

\section{Discussion}

Regarding farmers' perception of extreme weather events and production factors, the relatively low standard deviation of "heat" clearly indicates that the majority of the respondents have almost the same perception about this event. However, the relatively high standard deviation of "longer 
precipitation period" and "length of growing season" indicates that the majority of the respondents have different opinions on those parameters. These differences in the perception may be due to the variation of the rainfall distribution across the study area. Farmers' perception of rainfall trends is usually linked to their farm yield. Empirical data collected in The Gambia has shown that, in general, precipitation has decreased, the length of the rainy season has decreased, and the frequency of extreme weather events such as drought and dust has increased during the past 50 years [31].

The difference of perceptions may be explained by the fact that farmers' perceptions of climate change are linked with their crop-climate interaction knowledge and the production outcomes associated with the new change [32]. Farmers' perceptions of climate change and variability are consistent with empirical data and findings observed by others authors. Dhanya and Ramachandran [33] found that in India, farmers' perceptions are in accordance with trend analysis done using meteorological variables. Sanfo et al. [34] found that farmers' perception is only marginally consistent with empirical weather data in a similar study conducted in Burkina Faso.

The use of chemical fertilizers is revealed to be the farmers' stated preferred adaptation measure. This is in line with the works from Eguavoen and Wahren [35] who conducted a study on climate change adaptation in the South-West Region of Burkina Faso. A study conducted in Bangladesh on the importance of the adaptation method according to the farmers, ranked irrigation first, which is included in water conservation techniques in this study [36].

Referring to the cost and effectiveness, farmers have stated their preference for the use of improved crop varieties, which was ranked first. However, selecting the use of chemical fertilizers as their preference does not mean that farmers are not rational. For them, the chemical fertilizers should be applied depending on whether you are using improved varieties, practicing crop rotation, using water conservation, and water diversion systems. One bag (50 kg) of chemical fertilizer, if available, can be used for hectares, whereas natural fertilizers require larger quantities of use. Some farmers also mentioned that natural fertilizers sometimes bring about pests and diseases. For them, the chemical fertilizers are the best if a farmer can afford the cost. The only difficulties that farmers encountered with the use of chemical fertilizers are their unavailability, the expense, and the lack of knowledge on when and how to apply it.

Surprisingly, sociodemographic factors such as annual income did not exhibit any statically significant influence on the implementation of chemical fertilizers. Hassan and Nhemachena [37] did not find any significant and clear relationship between gender and adoption of adaptation strategies. A study conducted in the Central-Northern part of Burkina Faso showed that sociodemographic factors are not important in farmers' adoption of adaptation measures [38]. However, some authors, such as Burton et al. [39], Dolisca et al. [40], found that gender has an influence in farmers' adoption of natural resource management practices. Our study revealed that smallholder farmers are likely to apply chemical fertilizers than those holding large-scale croplands. When the farm size is big, farmers are not able to cover the whole farm with chemical fertilizers. During the FGD, farmers mentioned that they only apply chemical fertilizers to a portion of their farm or for a specific crop, rather than on the whole farm. Perception variables significantly affect the implementation of chemical fertilizers. Farmers respond to the perceived change. A study conducted in Kenya showed that $85 \%$ of farmers responded to climate variability [24] by using irrigation systems, water harvesting, agro-forestry, early maturing, drought- and pest-tolerant crop varieties, and improved livestock marketing. In this study, crop rotation was the most implemented adaptation measure. This can be explained by the fact that the crop rotation system is easy to practice. Regarding vulnerability and severity, respondents considered the dryness as the main threat to their farming activities and perceived its consequences as the most severe in term of losses. Similarly, a study conducted in Ghana found that farmers believe their farms are extremely vulnerable to rainfall and drought variation [35]. Since the mean of withstanding flooding is 3.8, which is less than the mean of withstanding drought (3.3), most of the respondents feel that they can cope with flooding better than drought. 
According to the respondents, the crop rotation system is very productive but requires an abundance of land. For most farmers, the land is available; the only difficulty is the clearance of the land. Water conservation was the least implemented. This may be explained by the nondiversification of water conservation techniques. In fact, farmers from the study area claimed during the transect walk to only collect water from the river for their rice field through tidal or pumping systems. They do not harvest or conserve the rainwater for upland fields. Therefore, only places that are close to rivers and not affected by the salt intrusion are suitable for this cropping technique. There is also the cost associated with current water conservation techniques, which is not always affordable for most farmers. The cost was found to be a significant barrier to farmers' adoption of climate change adaptation measures [41,42]. The correlation analysis showed a significant relationship between some perception variables and farmer-stated implementation of the adaptation measures. The result of the binary logistic regression supports the previous statement. The result further shows that perception variables significantly affect the implementation of chemical fertilizers. Interestingly, it shows that farmers do not apply chemical fertilizers to overcome longer periods of drought or insufficient rainfall. They only apply it when they expect favorable weather conditions so that they will improve their productivity. Similar studies have found that farmers' perception of climate change can determine their adaptation options $[41,43]$.

\section{Conclusions}

Farmers in the CRR perceive changes in climate patterns. In general, they perceived an increase in the average annual temperature, extreme weather events such as drought and flood, and a decrease of the annual average precipitation and production factors such as length of growing season and quality of soil structure. Farmers perceived that they are vulnerable to both the evolution of climatic factors and extreme weather events. Drought was perceived by farmers as the most severe in terms of loss associated. Farmers take measures to deal with the changing climate among which the most implemented are the use of chemical fertilizers, natural fertilizers, improved varieties, and crop rotation. The use of chemical fertilizers was stated by farmers as the preferred adaptation measure. Farmers' perceptions of climate variability are significantly correlated with their adoption of adaptation measures. Some perception variables significantly influence the implementation of chemical fertilizers. The study suggested that policy makers should promote and subsidize the use of natural fertilizers which is not preferred by the farmers but is believed to be environmental friendly. Natural fertilizers should be promoted and be made available through practices such as crop-livestock integration systems. Furthermore, drought-tolerant crops should be made available at affordable prices to farmers. In addition, climate smart agriculture techniques such as the timely production and use of downscaled weather and climate information services (WCIS) should be promoted. Innovative WCIS dissemination channels (e.g., SMS, interactive voice response (IVR), and social media (WhatsApp and Facebook)) must be developed to reach farmers. Furthermore, whether index-based insurance facilities in the cropping system that compensates farmers affected by climate chocks could be explored. The present study has some limitations. The analysis was done globally on the entire selected communities without analyzing differences between the communities. The study further explores the relationship between farmers' perception of climate change and their stated adaptation measures but did not make use of theories. Future studies should elaborate more on this by using behavioral theories, such as the protection motivation theory, to further analyze the link between perception and implementation variables.

Author Contributions: A.R.B. conceived the paper rational and carried data collection under the supervision of W.M.F. W.M.F. contributed to the data analysis. A.R.B. wrote the general draft. I.O. edited and contributed to the interpretation of results and discussion. All authors participated to the final draft.

Funding: We received fund on field work from the German Federal Ministry of Education and Research (BMBF).

Acknowledgments: The study was conducted for the West African Science Service Centre on Climate Change and Adapted Land Use (www.wascal.org) and funded by the German Federal Ministry of Education and Research. I'd like to thank Safi Sanfo and Irit Eguavoen for comments on earlier versions of this paper

Conflicts of Interest: The authors declare no conflict of interest. 


\section{References}

1. IPCC. Climate Change 2013: The Physical Science Basis. Contribution of Working Group I to the Fifth Assessment Report of the Intergovernmental Panel on Climate Change; Cambridge University Press: Cambridge, UK; New York, NY, USA, 2013; p. 1535.

2. Obayelu, O.A.; Adepoju, A.O.; Idowu, T. Factors influencing farmers' choices of adaptation to climate change in ekiti state, nigeria. J. Agric. Environ. Int. Dev. (JAEID) 2014, 108, 3-16.

3. IPCC. Climate Change 2007: Impacts, Adaptation and Vulnerability. Contribution of Working Group Ii to the Fourth Assessment Report of the Intergovernmental Panel on Climate Change; Parry, M.L., Canziani, O.F., Palutikof, J.P., van der linden, P.J., Hanson, C.E., Eds.; Cambridge University Press: Cambridge, UK, 2007; p. 976.

4. West, C.T.; Roncoli, C.; Ouattara, F. Local perceptions and regional climate trends on the central plateau of burkina faso. Land Degrad. Dev. 2008, 19, 289-304. [CrossRef]

5. ANR. Agriculture and Natural Resources (Anr) Policy; Government of The Gambia: Banjul, The Gambia, 2009.

6. Jatta, R. Hedging seasonal food price risks: The impact of cereal banking in the gambia. In Food Price Volatility and Its Implications for Food Security and Policy; Kalkuhl, M., von Braun, J., Torero, M., Eds.; Springer International Publishing: Cham, Switzerland, 2016; pp. 583-601.

7. NASS. National Agricultural Sample Survey; Planning Services Unit (PSU): Banjul, The Gambia, 2013.

8. Terdoo, F.; Feola, G. The vulnerability of rice value chains in sub-saharan africa: A review. Climate 2016, 4, 47. [CrossRef]

9. Yaffa, S. Coping measures not enough to avoid loss and damage from drought in the north bank region of the gambia. Int. J. Glob. Warm. 2013, 5, 467-482. [CrossRef]

10. Jones, P.G.; Thornton, P.K. The potential impacts of climate change on maize production in africa and latin america in 2055. Glob. Environ. Chang. 2003, 13, 51-59. [CrossRef]

11. Adesina, A.A.; Baidu-Forson, J. Farmers' perceptions and adoption of new agricultural technology: Evidence from analysis in burkina faso and guinea, west africa. Agric. Econ. 1995, 13, 1-9. [CrossRef]

12. Meijer, S.S.; Catacutan, D.; Ajayi, O.C.; Sileshi, G.W.; Nieuwenhuis, M. The role of knowledge, attitudes and perceptions in the uptake of agricultural and agroforestry innovations among smallholder farmers in sub-saharan africa. Int. J. Agric. Sustain. 2015, 13, 40-54. [CrossRef]

13. Deressa, T.T.; Hassan, R.M.; Ringler, C. Perception of and adaptation to climate change by farmers in the nile basin of ethiopia. J. Agric. Sci. 2011, 149, 23-31. [CrossRef]

14. Ochieng, J.; Kirimi, L.; Makau, J. Adapting to climate variability and change in rural kenya: Farmer perceptions, strategies and climate trends. Nat. Resour. Forum 2016, 41, 195-208. [CrossRef]

15. Sanfo, S.; Fonta, W.M.; Diasso, U.J.; Nikiéma, M.P.; Lamers, J.P.A.; Tondoh, J.E. Climate and environment-induced inter-village migration in southwestern burkina faso, west africa. Weather Clim. Soc. 2017. [CrossRef]

16. Maddison, D. The Perception of and Adaptation to Climate Change in Africa; The World Bank: Washington, DC, USA, 2007; p. 53.

17. Eguavoen, I.; Schulz, K.; de Wit, S.; Weisser, F.; Müller-Mahn, D. Political dimensions of climate change adaptation: Conceptual reflections and african examples. In Handbook of Climate Change Adaptation; Springer: Berlin/Heidelberg, Germany, 2015; pp. 1183-1199.

18. Mertz, O.; D’haen, S.; Maiga, A.; Moussa, I.B.; Barbier, B.; Diouf, A.; Diallo, D.; Da, E.D.; Dabi, D. Climate variability and environmental stress in the sudan-sahel zone of west africa. AMBIO 2012, 41, 380-392. [CrossRef]

19. Ehiakpor, D.S.; Danso-Abbeam, G.; Baah, J.E.; Yildiz, F. Cocoa farmer's perception on climate variability and its effects on adaptation strategies in the suaman district of western region, ghana. Cogent Food Agric. 2016, 2, 1210557.

20. Spence, A.; Poortinga, W.; Butler, C.; Pidgeon, N.F. Perceptions of climate change and willingness to save energy related to flood experience. Nat. Clim. Chang. 2011, 1, 46-49. [CrossRef]

21. Ayanlade, A.; Radeny, M.; Morton, J.F. Comparing smallholder farmers' perception of climate change with meteorological data: A case study from southwestern nigeria. Weather Clim. Extrem. 2017, 15, 24-33. [CrossRef]

22. Habtemariam, L.T.; Gandorfer, M.; Kassa, G.A.; Heissenhuber, A. Factors influencing smallholder farmers' climate change perceptions: A study from farmers in ethiopia. Environ. Manag. 2016, 58, 343-358. [CrossRef] 
23. Dolisca, F.C.; Douglas, R.; McDaniel, J.M.S.; Dennis, A.; Jolly, C.M. Factors influencing farmers' participation in forestry management programs: A case study from haiti. For. Ecol. Manag. 2006, 236, 324-331. [CrossRef]

24. Ndambiri, H.K.; Ritho, C.N.; Mbogoh, S.G. An evaluation of farmers'perceptions of and adaptation to the effects of climate change in kenya. Int. J. Food Agric. Econ. (IJFAEC) 2013, 1, 75-96.

25. Jallow, B.P.; Barrow, M.K.A.; Leatherman, S.P. Vulnerability of the coastal zone of the gambia to sea level rise and development of response strategies and adaptation options. Clim. Res. 1996, 6, 165-177. [CrossRef]

26. Gentle, J.E. Random Number Generation and Monte Carlo Methods; Springer: New York, NY, USA, 2003; Volume 2.

27. Dudovskiy, J. The Ultimate Guide to Writing a Dissertation in Business Studies: A Step-by-Step Assistance; Corwin: Thousand Oaks, CA, USA, 2016.

28. Karrer, S.L. Swiss Farmers' Perception of and Response to Climate Change; ETH Zurich: Zürich, Switzerland, 2012.

29. FAO. Reconnaissance Visit and Transect Walk. Available online: http://www.fao.org/fileadmin/templates/nr/ kagera/Documents/LADA_manuals/part2_b.pdf (accessed on 3 October 2014).

30. Stewart, D.; Shamdasani, P.; Rook, D. Focus Groups, 2nd ed.; Sage Publications, Inc.: Thousand Oaks, CA, USA, 2007.

31. NAPA. National Adaptation Programe of Action on Climate Change; Government of The Gambia: Banjul, The Gambia, 2007; p. 105.

32. Vedwan, N.; Rhoades, R.E. Climate change in the western himalayas of india: A study of local perception and response. Clim. Res. 2001, 19, 109-117. [CrossRef]

33. Dhanya, P.; Ramachandran, A. Farmers' perceptions of climate change and the proposed agriculture adaptation strategies in a semi arid region of south india. J. Integr. Environ. Sci. 2016, 13, 1-18.

34. Sanfo, S.; Lamers, J.; Mueller, M.; Fonta, W. Farmers' perception of climate change and climate variability versus climatic evidence in burkina faso, west africa. In Proceedings of the Climate Change in Africa. Negotiations, Translations, and Socio-Political Implications, Bonn, Germany, 10-12 September 2014.

35. Eguavoen, I.; Wahren, J. Climate change adaptation in burkina faso: Aid dependency and obstacles to political participation; ZEF Working Paper Series; Center for Development Research (ZEF), University of Bonn: ZBonn, Germany, 2015.

36. Uddin, M.N.; Bokelmann, W.; Entsminger, J.S. Factors affecting farmers' adaptation strategies to environmental degradation and climate change effects: A farm level study in bangladesh. Climate 2014, 2, 223-241. [CrossRef]

37. Hassan, R.; Nhemachena, C. Determinants of african farmers' strategies for adapting to climate change: Multinomial choice analysis. Afr. J. Agric. Resour. Econ. 2008, 2, 83-104.

38. Ouedraogo, S. Déterminants économiques, sociodémographiques et institutionnels de l'adoption et de l'intensité d'utilisation de la culture attelée dans le centre-nord du burkina faso. Ann. Univ. Ouagadougou Sér. B 2003, 1, 103-137.

39. Burton, M.; Rigby, D.; Young, T. Analysis of the determinants of adoption of organic horticultural techniques in the uk. J. Agric. Econ. 1999, 50, 47-63. [CrossRef]

40. Limantol, A.M.; Keith, B.E.; Azabre, B.A.; Lennartz, B. Farmers' perception and adaptation practice to climate variability and change: A case study of the vea catchment in ghana. SpringerPlus 2016, 5, 830. [CrossRef]

41. Bagagnan, A.R.; Ouedraogo, I.M.; Fonta, W.; Sowe, M.; Wallis, A. Can protection motivation theory explain farmers' adaptation to climate change decision making in the gambia? Climate 2019, 7, 13. [CrossRef]

42. Yameogo, T.; Emma, P.; Bontogho, K.; Torou, B.; Rasmane Bagagnan, A.; Barry, B. Barriers to uptake of climate-smart agriculture practices: A case study of dano and ouahigouya farmers, burkina faso. Int. J. Agric. Environ. Res. 2017, 3, 3409-3428.

43. Ogalleh, S.; Vogl, C.; Eitzinger, J.; Hauser, M. Local perceptions and responses to climate change and variability: The case of laikipia district, kenya. Sustainability 2012, 4, 3302. [CrossRef]

(C) 2019 by the authors. Licensee MDPI, Basel, Switzerland. This article is an open access article distributed under the terms and conditions of the Creative Commons Attribution (CC BY) license (http://creativecommons.org/licenses/by/4.0/). 